\title{
Rencana Produksi Pengangkutan Overburden Berdasarkan Pola Hujan di PT X Site Asam-Asam, Desa Riam Andungan, Kecamatan Kintap, Kabupaten Tanah Laut, Provinsi Kalimantan Selatan
}

\author{
Abdulah*, Maryanto \\ Prodi Teknik Pertambangan, Fakultas Teknik, Universitas Islam Bandung, \\ Indonesia. \\ *ambajry@gmail.com, maryanto_geo@unisba.ac.id
}

\begin{abstract}
PT X is a subsidiary of PT Pama Persada which is engaged in coal mining by using an open pit system, so that its mining activities are very much needed in the weather. Based on production output data, monthly production targets are not achieved, displayed in 2018 and 4 months of which production targets are not achieved in May, August, September, and December. This causes erratic rain that can be canceled due to mining activities. That way it needs to be reviewed in determining production targets based on rain predictions. In this research an analysis is performed first, then data processing is performed using rain classification, traffic classification, and productivity calculation. The results of this study on the correlation analysis of the relationship between rain hours to rainfall, slippery, and rainfall intensity are all three influential, it's just that the effect is very strong based on the correlation test that is the rainfall intensity with a significant value $<0.05$ and the correlation value 0.704 is at intervals $0.61-0.80$, including the strong correlation category. Then the results of rain hour forecasting in January 2019 are 71.25 hours, February 2019 is 53.92 hours, and in March 42.06 hours. For forecasting slippery time in January 2019 is 23.97 , in February 2019 that is 18.18, and in March 201914.30 hours. Calculation of monthly production targets is based on forecasting rain hours, the results of forecasting production targets for 2019 in January are 1,205,331.64 BCM, February 1,106,561.46 BCM, in March 1,406,595.41 BCM.
\end{abstract}

Keywords: Rain, Slippery, Rain Prediction, Productivity, Production Target.

Abstrak. PT X merupakan anak perusahaan dari PT Pama Persada yang bergerak di bidang penambangan batubara dengan menerapkan sistem tambang terbuka (Surface Mining), sehingga dalam kegiatan penambangannya sangat bergantung pada keadaan cuaca. Berdasarkan data hasil produksi, tidak tercapainya target produksi perbulan, tercatat pada tahun 2018 terdapat 4 bulan yg tidak tercapainya target produksi yaitu pada bulan Mei, Agustus, September, dan Desember. Hal tersebut disebabkan keadaan hujan yang tidak menentu yang dapat menghentikan aktivitas kegiatan tambang. Dengan begitu perlu dilakukan pengkajian ulang dalam menentukan target produksi berdasarkan prediksi hujan. Dalam penelitian ini dilakukan analisis korelasi terlebih dahulu, keudian dilakukan pengolahan data dengan menggunakan klasifikasi intensitas hujan, tahap peramalan, dan perhitungan produktivitas. Hasil dari penelitian ini pada analisis korelasi hubungan antara jam hujan terhadap curah hujan, slippery, dan intensitas hujan ketiganya berpengaruh, hanya saja nilai yang pengaruhnya sangat kuat berdasarkan uji korelasi yaitu intensitas hujan dengan nilai signifikan $<0,05$ dan nilai korelasi 0,704 berada pada interval $0,61-0,80$ termasuk kategori korelasi kuat. Kemudian hasil dari peramalan jam hujan pada bulan januari 2019 yaitu 71,25 jam, bulan februari 2019 yaitu 53,92 jam, dan pada bulan maret 42,06 jam. Untuk peramalan waktu slippery pada bulan januari 2019 yaitu 23,97, pada bulan februari 2019 yaitu 18,18, dan pada bulan maret 2019 14,30 jam. Perhitungan target produksi bulanan berdasarkan peramalan jam hujan, hasil peramalan target produksi tahun 2019 pada bulan Januari yaitu 1.205.331,64 BCM, bulan Februari 1.106.561,46 BCM, pada bulan Maret 1.406.595,41 BCM.

Kata Kunci: Hujan, Slippery, Prediksi Hujan, Produktivitas, Target Produksi. 


\section{A. Pendahuluan}

\section{Latar Belakang}

Iklim adalah bagian dari komponen ekosistem yang sangat berpengaruh bagi kehidupan manusia, temasuk di bidang pertambangan. Akan tetapi, iklim memiliki sifat yang dinamis dan sulit dikendalikan. Keadaan iklim dapat berubah-ubah seiring berjalannya waktu. analisis terhadap karakteristik iklim diperlukan agar kondisi iklim suatu daerah dapat lebih dipahami salah satunya yaitu hujan.

Tambang terbuka adalah suatu metode penambangan yang segala kegiatan dan aktivitas penambangannya dilakukan di atas permukaan bumi, dan tempat kerjanya berhubungan langsung dengan udara luar, dan faktor yang sangat berpengaruh dalam metode penambangannya yaitu hujan. Dengan adanya hujan maka kegiatan penambangan terhenti dikarenakan masalah keselamatan. Dengan berhentinya kegiatan maka target produksi menjadi tidak maksimal.

PT X merupakan perusahaan yang bergerak di bidang penambangan batubara dengan menerapkan sistem tambang terbuka (Surface Mining), sehingga dalam kegiatan penambangannya sangat bergantung pada keadaan cuaca. Berdasarkan data hasil produksi, tidak tercapainya target produksi perbulan, tercatat pada tahun 2018 terdapat 4 bulan yg tidak tercapainya target produksi yaitu pada bulan Mei, Agustus, September, dan Desember. Hal tersebut disebabkan keadaan hujan yang tidak menentu yang dapat menghentikan aktivitas kegiatan tambang. Dengan begitu perlu dilakukan pengkajian ulang dalam menentukan target produksi berdasarkan prediksi hujan. Dalam prosesnya digunakan metode peramalan untuk melakukan prediksi hujan yang akan datang.

\section{Tujuan Penelitian}

1. Mengetahui hubungan dan pengaruh antara jam hujan terhadap curah hujan, slippery, dan intensitas hujan.

2. Memprediksi jam hujan dan slippery bulanan pada tahun 2019.

3. Menentukan target produksi bulanan berdasarkan hasi prediksi hujan.

\section{B. Landasan Teori}

Menurut Kotler (2005:277) menyatakan bahwa, "Iklan adalah segala bentuk presentasi nonpribadi dan promosi gagasan, barang, atau jasa oleh sponsor tertentu yang harus dibayar." Menurut Saladin (2003:219) menyatakan bahwa, "Advertising adalah salah satu alat promosi, biasanya digunakan untuk mengarahkan komunikasi persuasif pada pembeli sasaran dan masyarakat dimana bentuk penyajian iklan ini bersifat non-personal".

\section{Hidrologi}

Hidrologi adalah suatu siklus tentang air yang berada di dalam bumi ini, baik perputarannya, pergerakannya, serta penyebarannya. Iklim dan cuaca salah satu pengaruh besar dalam metode tambang terbuka sehingga akan mempengaruhi kegiatan penambangan. Variabel intinya yaitu adanya hujan, yang dapat mempengaruhi kondisi tempat kerja, kerja alat dan kondisi pekerja, yang nantinya dapat mempengaruhi produktivitas tambang.

\section{Analisis Korelasi}

Analisis Korelasi adalah metode statistika yang digunakan untuk menentukan kuatnya atau derajat hubungan linier antara dua variabel atau lebih. Semakin nyata hubungan linier (garis lurus), maka semakin kuat atau tinggi derajat hubungan garis lurus antara kedua variabel atau lebih. Ukuran untuk derajat hubungan garis lurus ini dinamakan koefisien korelasi. Sebelum dilakukan analisis korelasi terlebih dahulu dilakukan uji outlier untuk memisahkan data yang tidak konsisten terhadap kumpulan data keseluruhan. Kemudian dilakukan uji normalitas untuk menguji apakah distribusi variabel terikat untuk setiap nilai variabel bebas tertentu berdistribusi normal atau tidak.

\section{Peramalan}


Peramalan adalah apa yang akan terjadi pada waktu yang akan datang melalui studi masa lalu. Dalam hal ini data jam hujan yang akan diramal agar diketahui waktu hambatan dari hujannya. Melakukan aktivitas peramalan perlu didasari dengan metode yang tepat dan terstandarisasi, hal ini dilakukan untuk dapat memberikan proyeksi masa depan yang jelas dan dapat dipertanggung jawabkan dasar pemikirannya. Time series Forecasting merupakan analisis deret waktu yang terdiri dari trend, seasonal, cycle, dan random variation. Analisis deret waktu ini sangat tepat dipakai untuk meramalkan permintaan yang pola permintaan di masa lalunya cukup konsisten dan akurat dalam periode waktu yang lama.. Sumproduct yaitu salah satu teknik peramalan time series yang hanya berdasarkan perilaku data variabel yang diamati. Teknik analisis data ini merupakan teknik untuk mencari pola yang paling cocok dari sekelompok data dengan memanfaatkan data masa lalu dan sekarang untuk melakukan peramalan jangka pendek yang akurat. Dalam peramalan ini perhitungannya dilihat dari nilai interval yang ada Peramalan dengan menggunakan model sumproduct ini dapat dilakukan dengan rumus sebagai berikut :

$$
\text { sumproduct }=\frac{(\mathrm{a} 1 \times \mathrm{b} 1)+(\mathrm{a} 2 \times \mathrm{b} 2)+(\mathrm{a} 3 \times \mathrm{b} 3)+\ldots}{\sum \mathrm{b}} \times \bar{x} \mathrm{n}
$$

$$
\begin{aligned}
& \text { Keterangan : } \\
& \mathrm{a} \quad=\text { nilai persentase frekuensi data dari setiap interval } \\
& \mathrm{b} \quad=\text { nilai rata-rata data dari setiap interval } \\
& \overline{\mathrm{x}} \mathrm{n}=\text { rata-rata dari jumlah data }
\end{aligned}
$$

Faktor Yang Mempengaruhi Produksi

Prediksi hujan dikatakan baik jika hasil produksi yang diharapkan dapat terpenuhi secara ekonomis. Ada beberapa faktor yang mempengaruhi produksi tersebut. Dilihat dalam perhitungan produktivitas pada alat muat dapat dirumuskan sebagai berikut :

$$
\mathrm{Pm}=\frac{(3600 \times \mathrm{Em}) \times \mathrm{Hm} \times \mathrm{SF} \times \mathrm{FFm}}{\mathrm{CTm}}
$$

Keterangan :

$\begin{array}{ll}\mathrm{Pm} & =\text { Produktivitas alat muat }(\mathrm{BCM} / \mathrm{jam} / \mathrm{unit}) \\ \mathrm{Hm} & =\text { Kapasitas bucket alat muat }(\mathrm{BCM}) \\ \mathrm{FFm} & =\text { Fill Factor }=\text { Faktor pengisian alat muat }(\%) \\ \mathrm{Em} & =\text { Effisiensi kerja alat muat }(\%) \\ \mathrm{SF} & =\text { Swell Factor }(\%) \\ \mathrm{CTm} & =\text { Waktu edar alat muat (detik) } \\ 3600 & =\text { konversi satuan waktu (detik ke jam) } \\ \text { Untuk memperoleh produksi yang diinginkan ada beberapa faktor yang harus }\end{array}$ diperhatikan, antara lain :

1. Efisiensi kerja

Efisiensi kerja adalah perbandingan antara waktu kerja produktif dengan waktu kerja yang tersedia. Waktu kerja yang digunakan adalah waktu untuk produksi, berarti ada kehilangan waktu yang disebabkan oleh adanya hambatan-hambatan selama jam kerja. Dengan memperhitungkan hambatan-hambatan tersebut, maka jam kerja efektif dapat dihitung dengan menggunakan persamaan sebagai berikut :

$$
W e=W p-W h
$$

Keterangan :

$$
\begin{aligned}
& \mathrm{We} \quad \text { = Waktu kerja efektif, (menit) } \\
& \mathrm{Wp} \quad \text { = Waktu untuk berproduksi / waktu yang tersedia, (menit) } \\
& \mathrm{Wh} \quad \text { = Waktu-waktu hambatan, (menit) }
\end{aligned}
$$


Dengan didapatkan hasil waktu kerja efektif, maka dapat dilakukan perhitungan efisiensi kerja. Untuk menghitung efisiensi kerja digunakan rumus :

$$
E=\frac{W e}{W p} \times 100 \%
$$

Keterangan:

$\mathrm{E} \quad=$ Efisiensi kerja (\%)

$\mathrm{We} \quad=$ Waktu kerja efektif (menit)

$\mathrm{Wp} \quad=$ Waktu kerja produktif (menit)

2. Waktu Edar (Cycle Time)

Cycle time merupakan jumlah waktu yang diperlukan oleh suatu alat untuk melakukan satu siklus kegiatan. Hal tersebut dapat dilihat dari kemampuan alat tersebut dalam penggunaannya di lapangan. dapat dihitung dengan menggunakan rumus sebagai berikut :

$$
C T_{m}=T_{1}+T_{2}+T_{3}+T_{4}
$$

Keterangan :

$\mathrm{CTm}=$ Cyle time alat muat (menit)

$\mathrm{T} 1=$ Waktu mengisi bucket (menggali), detik

$\mathrm{T} 2=$ Waktu ayunan bermuatan, detik

T3 = Waktu menumpahkan isi, detik

T4 = Waktu ayunan kosong, detik

\section{Hasil Penelitian dan Pembahasan}

\section{Analisis Korelasi}

Analisis korelasi yaitu satu teknik analisis dalam statistik yang digunakan untuk mengetahui kekuatan hubungan antara kedua variabel, Kedua variabel yang dibandingkan satu sama lain dalam korelasi dapat dibedakan menjadi variabel terikat dan variabel bebas. Analisis penelitian ini menggunakan analisis korelasi Pearson Product Moment dengan tujuan untuk mengetahui hubungan dari pengaruh jam hujan (variabel terikat) terhadap curah hujan, slippery, dan intensitas hujan (variabel bebas). Sebelum dilakukan analisis korelasi terlebih dahulu dilakukan uji outlier dan uji normalitas.

1. Uji Outlier

Pada tahap pengolahan data ini terlebih dahulu dilakukan uji outlier, karena salah satu alasan mengapa data tidak normal adalah adanya outlier. Outlier adalah data yang memiliki nilai ekstrem, baik ekstrem tinggi maupun ekstrem rendah. Dalam pencarian outlier ini dilakukan dengan menggunakan bantuan Software SPSS 23 dengan melihat data jam hujan (variabel tetap). Hasil dari pencarian tersebut terdapat 9 data outlier.

Tabel 1. Data Outlier

\begin{tabular}{|l|c|c|c|c|}
\hline \multirow{2}{*}{ DATE } & Curah Hujan & Jam Hujan & Slippery & Intensitas CH \\
\cline { 2 - 5 } & $(\mathrm{mm})$ & (hrs) & (hrs) & $\mathrm{mm} / \mathrm{jam}$ \\
\hline 9 Mei 2016 & 36,00 & 9,78 & 3,25 & 3,68 \\
\hline 23 Mei 2016 & 43,00 & 10,32 & 3,17 & 4,17 \\
\hline 1 Agusutus 2016 & 24,00 & 9,59 & 4,53 & 2,50 \\
\hline
\end{tabular}

JRTP is licensed under Creative Commons Attribution- 


\begin{tabular}{|l|c|c|c|c|}
\hline 4 Agusutus 2016 & 23,00 & 9,66 & 3,09 & 2,38 \\
\hline 28 Oktober 2016 & 38,00 & 12,21 & 2,22 & 3,11 \\
\hline 1 Juli 2017 & 24,00 & 12,31 & 3,40 & 1,95 \\
\hline 19 November 2017 & 43,00 & 10,00 & 2,35 & 4,30 \\
\hline 21 November 2017 & 28,00 & 9,54 & 3,44 & 2,94 \\
\hline 8 Januari 2018 & 24,00 & 9,81 & 1,15 & 2,45 \\
\hline
\end{tabular}

2. Uji Normalitas

Setelah diketahui nilai outlier, maka selanjutnya dilakukan uji normalitas terlebih dahulu. Uji normalitas ini berguna untuk menguji apakah dalam analisis korelasi variabel tetap dan variabel bebas memiliki distribusi normal atau tidak. Dalam pengujian tentang kenormalan distribusi data tersebut, dilakukan menggunakan Software SPSS 23 dengan rumus Kolmogorov-Smirnov. Hasil uji normalitas data yang dihitung dengan rumus Kolmogorov-smirnov diperoleh data sebagai berikut :

Tabel 2. Hasil Uji Normalitas jam hujan (Y) Tests of Normality

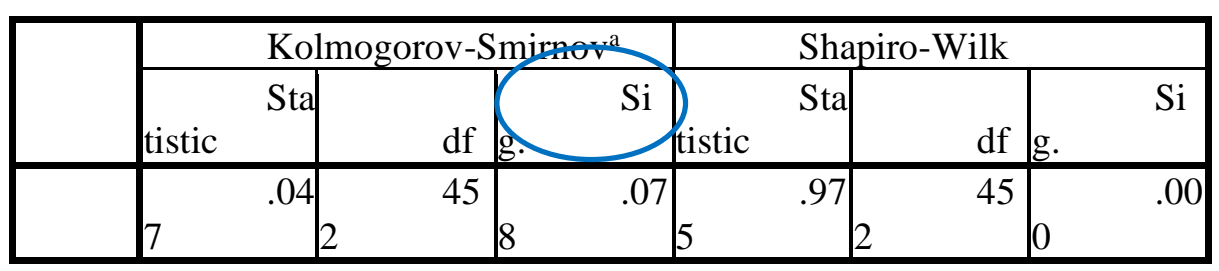

a. Lilliefors Significance Correction

Tabel 3. Hasil Uji Normalitas Curah Hujan Tests of Normality

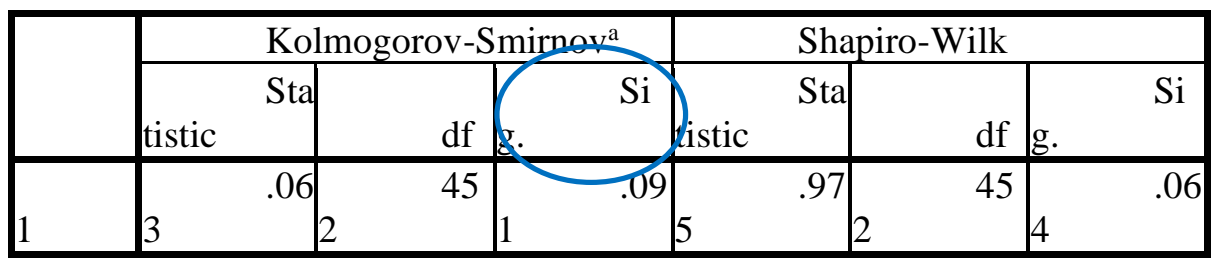

a. Lilliefors Significance Correction

Tabel 4. Hasil Uji Normalitas Slippery Tests of Normality

\begin{tabular}{|c|c|c|c|c|c|c|c|c|}
\hline & \multicolumn{3}{|c|}{ Kolmogorov-Smirnov ${ }^{\mathrm{a}}$} & \multicolumn{3}{|c|}{$\begin{array}{l}\text { Shapiro-Wilk } \\
\text { Stal }\end{array}$} & & \multirow[b]{2}{*}{$\mathrm{Si}$} \\
\hline & tistic & $d f$ & & tistic & Sta & $\mathrm{df}$ & & \\
\hline 2 & .03 & 45 & .06 & 5 & .97 & 45 & 9 & .02 \\
\hline
\end{tabular}

a. Lilliefors Significance Correction

Tabel 5. Hasil Uji Normalitas Intesitas Hujan Tests of Normality

\begin{tabular}{|l|l|}
\hline Kolmogorov-Smirnov $^{\mathrm{a}}$ & Shapiro-Wilk \\
\hline
\end{tabular}




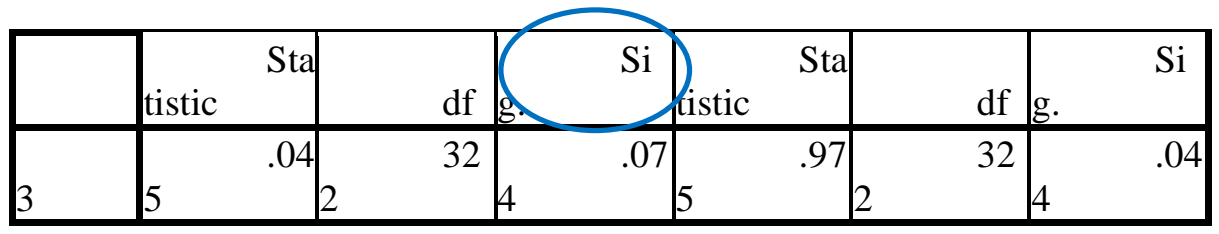

a. Lilliefors Significance Correction

Berdasarkan tabel di atas terlihat bahwa data tersebut dikatakan normal. Hal ini dibuktikan dengan nilai Sig. pada Tabel 2 nilai jam hujan yaitu 0,078, pada Tabel 3 nilai curah hujan yaitu 0,091, pada Tabel 4 nilai sliperry yaitu 0,062 , dan pada Tabel 5 nilai Intensitas Hujan yaitu 0,074 . Dengan hasil tersebut maka data tersebut berdistribusi normal, dikarenakan semua nilainya lebih besar dari nilai 0,05 . Nilai signifikan semuanya $<0,05$. Maka dilihat kembali nilai koefisien korelasinya untuk mengetahui hubungan keeratan antara variabel tersebut, dan hubungan yang paling kuat dengan jam hujan yaitu intensitas hujan dengan nilai korelasi 0,704 dengan kategori korelasi kuat. Dengan demikian variabel yang digunakan dalam pengolahan data peramalan yaitu intensitas hujan.

\section{Perhitungan Klasifikasi Intensitas Hujan}

1. Pengelompokan Data Intensitas Hujan

Pada tahap awal ini data intensitas hujan dikelompokkan perbulan berdasarkan data 3 tahun terakhir dari tahun 2016 - 2018. Pengelompokan ini dilakukan karena dalam peramalan jam hujan satuan waktu yang digunakan adalah perbulan. Adapun contoh hasil pengelompokan data intensitas hujan pada bulan Januari, Februari, dan Maret sebagai berikut :

Tabel 6. Hasil Pengelompokan Data Intensitas Hujan Perbulan

\begin{tabular}{|c|c|c|c|c|c|c|c|c|}
\hline \multicolumn{7}{|c|}{ Intensitas Hujan (mm/jam) } \\
\hline 2016 & 2017 & 2018 & 2016 & 2017 & 2018 & 2016 & 2017 & 2018 \\
\hline 1,98 & 4,50 & 1,51 & 2,50 & 3,07 & 1,46 & 3,12 & 2,15 & 2,99 \\
\hline 1,76 & 3,74 & 1,39 & 2,65 & 4,19 & 3,02 & 3,40 & 2,74 & 4,00 \\
\hline 2,50 & 1,48 & 1,92 & 2,23 & 2,81 & 1,25 & 2,40 & 2,82 & 4,69 \\
\hline 1,41 & 1,80 & 2,76 & 3,05 & 1,17 & 2,30 & 2,60 & 4,91 & 6,77 \\
\hline 1,89 & 1,28 & 1,63 & 2,15 & 1,58 & 1,54 & 1,34 & 1,64 & 2,76 \\
\hline 3,23 & 2,84 & 2,45 & 1,41 & 1,36 & 2,05 & 2,14 & 2,27 & 2,00 \\
\hline 2,08 & 1,08 & 1,91 & 3,28 & 23,72 & 1,49 & 3,64 & 1,32 & 1,28 \\
\hline 2,20 & 1,73 & 2,96 & 2,58 & 1,64 & 2,00 & 3,75 & 1,79 & 11,00 \\
\hline 1,92 & 1,75 & 1,41 & 1,60 & 1,37 & 1,20 & & 2,70 & 2,43 \\
\hline 2,10 & 5,16 & 1,26 & 2,19 & 3,00 & 1,40 & & 3,01 & 2,86 \\
\hline 1,30 & 2,16 & 1,90 & 3,35 & 1,61 & 2,78 & & 1,95 & 5,17 \\
\hline
\end{tabular}




\begin{tabular}{|c|c|c|c|c|c|c|c|c|}
\hline 2,33 & 3,50 & 5,01 & 1,92 & 1,47 & 2,03 & & 1,97 & 6,19 \\
\hline 1,56 & 4,89 & 2,87 & 2,08 & 1,60 & 1,67 & & 1,67 & 3,79 \\
\hline 5,47 & 2,86 & 2,19 & 1,59 & 2,88 & 1,59 & & 2,15 & \\
\hline 2,72 & 17,19 & 3,85 & & & 1,46 & & 1,80 & \\
\hline 2,24 & 5,83 & 2,17 & & & 2,91 & & 2,76 & \\
\hline 1,73 & 2,82 & 1,17 & & & 4,48 & & 1,61 & \\
\hline 4,36 & & 1,99 & & & & & 10,04 & \\
\hline & & 1,17 & & & & & & \\
\hline
\end{tabular}

2. Klasifikasi Intensitas Hujan

Setelah dilakukan tahap pengelompokan, selanjutnya pengklasifikasian intensitas curah hujan. Dalam klasifikasi ini dilakukan pengelompokan kriteria intensitas hujan perbulan berdasarkan nilai intensitas hujan dari tahun 2016 - 2018. Pengklasifikasian intensitas hujan ini dilakukan guna mempermudah dalam peramalan jam hujan. Dalam pengelompokan ini data yang digunakan yaitu data hasil tahap pengelompokan sebelumnya. Klasifikasi intensitas hujan yang digunakan berdasarkan (Mori, 1977).

Tabel 7. Klasifikasi curah hujan menurut standar internasional WMO

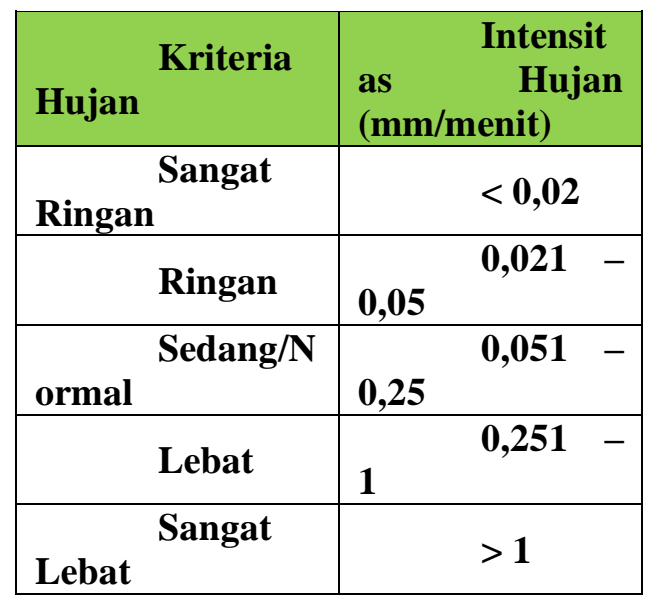

Sumber : (Mori, 1997)

Berdasarkan klasifikasi di atas data intensitas hujan pada bulan Januari dengan kurun waktu 3 tahun terakhir, intensitas hujan paling banyak berada pada kriteria hujan ringan dengan frekuensi 39 dengan persentase $70 \%$, dan intensitas paling sedikit berada pada kriteria hujan lebat dengan frekuensi 1 dengan persentase 2\% dari total 56 data hari hujan pada bulan januari kurun waktu 3 tahun. Hasil tersebut dapat dilihat pada Tabel 8.

Tabel 8. Hasil Klasifikasi Intensitas Hujan Bulan Januari

\begin{tabular}{|l|l|l|l|}
\hline Kriteri & Inten & Fr & H \\
\hline
\end{tabular}




\begin{tabular}{|c|c|c|c|}
\hline a Hujan & $\begin{array}{l}\text { sitas Hujan } \\
(\mathrm{mm} / \mathrm{menit})\end{array}$ & ekuensi & asil \% \\
\hline $\begin{array}{l}\text { Sangat } \\
\text { Ringan }\end{array}$ & $<\mathbf{0 , 0 2}$ & 3 & $\%$ \\
\hline Ringan & $-0,05{ }^{0,021}$ & 39 & $0 \%$ \\
\hline $\begin{array}{l}\text { Sedang/ } \\
\text { Normal }\end{array}$ & $-0,25{ }^{0,051}$ & 13 & $3 \%$ \\
\hline Lebat & $\begin{array}{rr} & 0,251 \\
-1 & \\
\end{array}$ & 1 & $\%$ \\
\hline $\begin{array}{ll}\text { Sangat } \\
\text { Lebat }\end{array}$ & $>1$ & 0 & $\%$ \\
\hline Total & & 56 & $00 \%$ \\
\hline
\end{tabular}

3. Klasifikasi Intensitas Hujan Berdasarkan Jam Hujan

Setelah didapatkan hasil data frekuensi dan persentase dari klasifikasi hujan berdasarkan data intensitas hujan, maka selanjutnya mencari jam hujan berdasarkan frekuensi setiap kriteria intensitas hujan, kemudian dicari nilai rata-rata jam hujan dari setiap kriteria hujan tersebut. Nilai rata-rata ini digunakan sebagai parameter dalam penentuan peramalan jam hujan. Adapun contoh hasil klasifikasi intensitas hujan berdasarkan jam hujan pada bulan Januari, Februari, dan Maret.

Tabel 9. Hasil Klasifikasi Intensitas Hujan Berdasarkan Jam Hujan

\begin{tabular}{|c|c|c|c|c|c|c|c|c|c|c|c|c|c|c|c|c|c|}
\hline \multirow{3}{*}{$\begin{array}{c}\text { No } \\
1\end{array}$} & \multicolumn{6}{|c|}{ Januari } & \multicolumn{6}{|c|}{ Februari } & \multicolumn{5}{|c|}{ Maret } \\
\hline & \multirow{2}{*}{\begin{tabular}{|c|}
$\begin{array}{c}\text { Sangat } \\
\text { Ringan }\end{array}$ \\
3,00 \\
\end{tabular}} & \multicolumn{2}{|c|}{ Ringan } & \multirow{2}{*}{\begin{tabular}{|c|}
$\begin{array}{l}\text { Sedang/ } \\
\text { Normal }\end{array}$ \\
7,11 \\
\end{tabular}} & \multirow{2}{*}{$\begin{array}{c}\text { Lebat } \\
1,92\end{array}$} & \multirow[t]{2}{*}{$\begin{array}{c}\text { Sangat } \\
\text { Lebat }\end{array}$} & \multirow{2}{*}{\begin{tabular}{|c|}
$\begin{array}{c}\text { Sangat } \\
\text { Ringan }\end{array}$ \\
2,56 \\
\end{tabular}} & \multicolumn{2}{|c|}{ Ringan } & \multirow{2}{*}{\begin{tabular}{|c|}
$\begin{array}{c}\text { Sedang/ } \\
\text { Normal }\end{array}$ \\
1,64
\end{tabular}} & \multirow{2}{*}{$\begin{array}{c}\text { Lebat } \\
1,56\end{array}$} & \multirow[t]{2}{*}{$\begin{array}{c}\text { Sangat } \\
\text { Lebat }\end{array}$} & \multirow[t]{2}{*}{$\begin{array}{l}\text { Sangat } \\
\text { Ringan }\end{array}$} & \multirow{2}{*}{$\begin{array}{c}\text { Ringan } \\
3,25\end{array}$} & \multirow{2}{*}{$\begin{array}{c}\begin{array}{c}\text { Sedang/ } \\
\text { Normal }\end{array} \\
2,08 \\
\end{array}$} & \multirow[t]{2}{*}{ Lebat } & \multirow[t]{2}{*}{$\begin{array}{l}\text { Sangat } \\
\text { Lebat }\end{array}$} \\
\hline & & 5,19 & 4,55 & & & & & 1,55 & 3,20 & & & & & & & & \\
\hline 2 & 2,56 & 1,14 & 3,12 & 5,12 & & & 3,51 & 7,46 & 4,15 & 4,27 & & & & 2,37 & 3,00 & & \\
\hline 3 & 2,32 & 2,31 & 6,41 & 6,00 & & & & 5,00 & 1,12 & 3,19 & & & & 2,48 & 1,10 & & \\
\hline 4 & & 3,15 & 1,77 & 5,61 & & & & 5,90 & 3,25 & 7,83 & & & & 3,04 & 0,80 & & \\
\hline 5 & & 7,09 & 4,75 & 2,71 & & & & 2,40 & 1,77 & 3,58 & & & & 3,96 & 6,72 & & \\
\hline 6 & & 2,65 & 2,16 & 2,52 & & & & 5,58 & 2,33 & 6,96 & & & & 3,04 & 1,33 & & \\
\hline 7 & & 1,80 & 3,63 & 4,86 & & & & 7,39 & 2,81 & 0,67 & & & & 3,90 & 2,39 & & \\
\hline 8 & & 1,04 & 5,74 & 1,33 & & & & 1,36 & 0,35 & & & & & 2,04 & 6,00 & & \\
\hline 9 & & 6,53 & 1,67 & 3,26 & & & & 6,34 & 3,58 & & & & & 2,56 & 8,80 & & \\
\hline 10 & & 3,06 & 1,54 & 6,59 & & & & 6,03 & 3,12 & & & & & 4,31 & 0,50 & & \\
\hline 11 & & 9,81 & 3,22 & 0,65 & & & & 3,00 & 1,44 & & & & & 2,39 & 2,75 & & \\
\hline 12 & & 6,82 & 2,89 & 0,90 & & & & 3,64 & 4,62 & & & & & 3,26 & 0,96 & & \\
\hline 13 & & 1,35 & 6,26 & 4,11 & & & & 5,03 & 3,16 & & & & & 1,67 & 0,96 & & \\
\hline 14 & & 5,31 & 3,12 & & & & & 2,71 & 3,31 & & & & & 1,45 & & & \\
\hline 15 & & 6,75 & 5,21 & & & & & 3,90 & 1,83 & & & & & 6,84 & & & \\
\hline 16 & & 1,68 & 3,44 & & & & & 3,78 & 5,11 & & & & & 7,50 & & & \\
\hline 17 & & 3,83 & 5,00 & & & & & 1,37 & 7,01 & & & & & 4,42 & & & \\
\hline 18 & & 2,74 & 3,91 & & & & & 1,75 & & & & & & 3,35 & & & \\
\hline 19 & & 1,84 & 6,17 & & & & & & & & & & & 1,40 & & & \\
\hline 20 & & 4,52 & & & & & & & & & & & & 4,17 & & & \\
\hline 21 & & & & & & & & & & & & & & 0,50 & & & \\
\hline 22 & & & & & & & & & & & & & & 0,78 & & & \\
\hline 23 & & & & & & & & & & & & & & 4,53 & & & \\
\hline 24 & & & & & & & & & & & & & & 4,20 & & & \\
\hline 25 & & & & & & & & & & & & & & 3,17 & & & \\
\hline 26 & & & & & & & & & & & & & & 8,20 & & & \\
\hline rata-rata & 2,63 & 3 , & 93 & 3,91 & 1,92 & 0,00 & 3,04 & 3, & 61 & 4,02 & 1,56 & 0,00 & 0,00 & 3,41 & 2,88 & 0,00 & 0,00 \\
\hline
\end{tabular}

4. Hari Hujan

Langkah terakhir dari pengolahan data ini yaitu menentukan jumlah dan rata-rata hari hujan bulanan dengan total data 3 tahun terakhir. Penentuan ini digunakan untuk perhitungan statistika dalam proses peramalan jam hujan tersebut.

Tabel 10. Jumlah Hari Hujan 


\begin{tabular}{|c|c|c|c|c|c|c|c|c|c|c|c|c|}
\hline \multicolumn{13}{|c|}{ Jumlah Hari Hujan } \\
\hline Tahun & Januari & Februari & Maret & April & Mei & Juni & Juli & Agustus & September & Oktober & November & Desember \\
\hline 2016 & 18 & 14 & 8 & 7 & 17 & 15 & 9 & 12 & 11 & 22 & 18 & 25 \\
\hline 2017 & 17 & 14 & 18 & 15 & 13 & 17 & 12 & 12 & 9 & 13 & 24 & 20 \\
\hline 2018 & 21 & 17 & 13 & 21 & 16 & 13 & 11 & 6 & 10 & 16 & 19 & 24 \\
\hline Rata-Rata & 19 & 15 & 13 & 14 & 15 & 15 & 11 & 10 & 10 & 17 & 20 & 23 \\
\hline
\end{tabular}

Berdasarkan data di atas dapat diketahui rata-rata bulan Januari dalam 3 tahun terakhir yaitu 19 hari, bulan Februari yaitu 15 hari, dan pada bulan Maret 13 hari.

\section{Model Matematis Peramalan}

Setelah didapatkan hasil dari pengolahan data di atas, selanjutnya dapat dilakukan peramalan jam hujan dengan menggunakan rumus statistika dengan bantuan Microsoft Excel. Dalam hal ini dilakukan peramalan jam hujan per bulan dan peramalan waktu slippery perbulan.

1. Peramalan Jam Hujan

Peramalan jam hujan dilakukan menggunakan rumus statistika dengan fungsi sumproduct, dengan variabel data yang digunakan yaitu hasil persentase intensitas hujan, rata-rata jam hujan berdasarkan klasifikasi hujan, dan rata-rata hari hujan perbulan. Dalam hal ini peramalan dilakukan menggunakan metode statistika dengan bantuan Microsoft excel berdasarkan fungsi sumproduct yaitu dengan rumus :

$$
\text { sumproduct }=\frac{(\mathrm{a} 1 \times \mathrm{b} 1)+(\mathrm{a} 2 \times \mathrm{b} 2)+(\mathrm{a} 3 \times \mathrm{b} 3)+\ldots}{\sum \mathrm{b}} \times \overline{\mathrm{x}} \mathrm{n}
$$

Denga rumus di atas maka perhitungan yang dilakukan untuk peramalan jam hujan per bulan yaitu Jam Hujan Efektif (JHE) dengan rumus sebagai berikut :

$$
J H E=\frac{(\% S R \times \bar{x} S R)+(\% R \times \bar{x} R)+(\% S \times \bar{x} S)+(\% L \times \bar{x} L)}{\bar{x} S R+\bar{x} R+\bar{x} S+\bar{x} L} \times \sum \text { Hari Hujan }
$$
berikut :

Dengan rumus di atas maka dapat dilakukan perhitungan teoritis perbulannya sebagai

$$
\text { Januari } 2019=\frac{(5 \% \times 2,63)+(70 \% \times 3,93)+(23 \% \times 3,91)+(2 \% \times 1,92)}{2,63+3,93+3,91+1,92} \times 19=71,25 \mathrm{jam}
$$

Dengan cara yang sama, maka bulan Februari 2019 hingga bulan Desember 2019 dapat dihitung dengan menggunakan rumus diatas. Hasil perhitungan dapat dilihat pada Tabel 11.

Tabel 11. Hasil Peramalan Jam Hujan Tahun 2019

\begin{tabular}{|c|c|c|c|c|c|c|}
\hline \multicolumn{7}{|c|}{ Peramalan 2019 (Jam Hujan) } \\
\hline & Forecast & $\begin{array}{c}\text { Historis } \\
2016\end{array}$ & $\begin{array}{c}\text { Historis } \\
2017\end{array}$ & $\begin{array}{c}\text { Historis } \\
\mathbf{2 0 1 8}\end{array}$ & $\begin{array}{c}\text { Rata-rata 3 } \\
\text { tahun }\end{array}$ & $\Delta$ t \\
\hline Januari & 71,25 & 71,71 & 66,64 & 77,54 & 71,96 & 0,72 \\
\hline Februari & 54,04 & 37,54 & 60,48 & 66,00 & 54,67 & 0,63 \\
\hline Maret & 42,06 & 23,65 & 57,57 & 47,15 & 42,79 & 0,73 \\
\hline April & 54,16 & 30,57 & 54,25 & 79,23 & 54,68 & 0,52 \\
\hline Mei & 40,17 & 56,04 & 25,67 & 40,16 & 40,62 & 0,45 \\
\hline Juni & 46,02 & 51,94 & 51,88 & 36,23 & 46,68 & 0,66 \\
\hline
\end{tabular}




\begin{tabular}{|c|c|c|c|c|c|c|}
\hline \multicolumn{7}{|c|}{ Peramalan 2019 (Jam Hujan) } \\
\hline & Forecast & $\begin{array}{c}\text { Historis } \\
\mathbf{2 0 1 6}\end{array}$ & $\begin{array}{c}\text { Historis } \\
\mathbf{2 0 1 7}\end{array}$ & $\begin{array}{c}\text { Historis } \\
\mathbf{2 0 1 8}\end{array}$ & $\begin{array}{c}\text { Rata-rata 3 } \\
\text { tahun }\end{array}$ & $\Delta \mathbf{t}$ \\
\hline Juli & 41,82 & 39,51 & 50,03 & 38,59 & 42,71 & 0,89 \\
\hline Agustus & 29,88 & 34,34 & 38,45 & 18,13 & 30,31 & 0,43 \\
\hline September & 23,31 & 28,13 & 26,00 & 18,03 & 24,05 & 0,75 \\
\hline Oktober & 59,06 & 79,63 & 36,11 & 63,48 & 59,74 & 0,68 \\
\hline November & 72,01 & 66,12 & 100,80 & 50,96 & 72,63 & 0,62 \\
\hline Desember & 75,48 & 73,72 & 68,19 & 85,05 & 75,65 & 0,18 \\
\hline
\end{tabular}

2. Peramalan waktu slippery

Setelah didapatkan hasil peramalan jam hujan, selanjutnya yaitu peramalan waktu slippery. Dalam peramalan ini dilakukan dengan cara melihat data total jam hujan dan total waktu slippery bulanan dari kurun waktu 2016 - 2018.

Setelah didapatkan hasil persentase slippery terhadap jam hujan, kemudian diambil nilai rata-rata persentasenya. Hasil perhitungan dalam kurun waktu 2016 -2018 berdasarkan waktu perbulan dapat dilihat pada Tabel 12

Tabel 12. Data Jam Hujan dan Slippery 2016 - 2018

\begin{tabular}{|l|c|c|c|l|c|c|c|}
\hline \multicolumn{1}{|c|}{ Bulan } & $\begin{array}{c}\text { jam } \\
\text { hujan }\end{array}$ & Slippery & hasil & \multicolumn{1}{|c|}{ Bulan } & $\begin{array}{c}\text { jam } \\
\text { hujan }\end{array}$ & Slippery & hasil \\
\hline Januari 2016 & 71,71 & 26,19 & $37 \%$ & Juli 2017 & 50,03 & 14,32 & $29 \%$ \\
\hline Februari 2016 & 37,54 & 15,88 & $42 \%$ & Agustus 2017 & 38,45 & 12,77 & $33 \%$ \\
\hline Maret 2016 & 23,65 & 7,54 & $32 \%$ & September 2017 & 26,02 & 8,29 & $32 \%$ \\
\hline April 2016 & 30,57 & 8,00 & $26 \%$ & Oktober 2017 & 36,11 & 12,18 & $34 \%$ \\
\hline Mei 2016 & 56,04 & 16,00 & $29 \%$ & November 2017 & 100,80 & 40,47 & $40 \%$ \\
\hline Juni 2016 & 51,94 & 18,21 & $35 \%$ & Desember 2017 & 68,19 & 24,28 & $36 \%$ \\
\hline Juli 2016 & 39,51 & 14,21 & $36 \%$ & Januari 2018 & 77,54 & 22,81 & $29 \%$ \\
\hline Agustus 2016 & 34,34 & 11,57 & $34 \%$ & Februari 2018 & 66,00 & 20,01 & $30 \%$ \\
\hline September 2016 & 28,13 & 9,50 & $34 \%$ & Maret 2018 & 47,15 & 16,41 & $35 \%$ \\
\hline Oktober 2016 & 79,63 & 33,55 & $42 \%$ & April 2018 & 79,23 & 26,40 & $33 \%$ \\
\hline November 2016 & 66,12 & 22,02 & $33 \%$ & Mei 2018 & 40,16 & 13,62 & $34 \%$ \\
\hline
\end{tabular}




\begin{tabular}{|l|c|c|c|l|c|c|c|}
\hline Desember 2016 & 73,72 & 29,14 & $40 \%$ & Juni 2018 & 36,23 & 12,08 & $33 \%$ \\
\hline Januari 2017 & 66,64 & 18,83 & $28 \%$ & Juli 2018 & 38,59 & 11,72 & $30 \%$ \\
\hline Februari 2017 & 60,48 & 18,18 & $30 \%$ & Agustus 2018 & 18,13 & 6,10 & $34 \%$ \\
\hline Maret 2017 & 57,57 & 18,60 & $32 \%$ & September 2018 & 18,03 & 6,71 & $37 \%$ \\
\hline April 2017 & 54,25 & 20,75 & $38 \%$ & Oktober 2018 & 63,48 & 18,83 & $30 \%$ \\
\hline Mei 2017 & 25,67 & 8,73 & $34 \%$ & November 2018 & 50,96 & 15,87 & $31 \%$ \\
\hline Juni 2017 & 51,88 & 16,37 & $32 \%$ & Desember 2018 & 85,05 & 32,04 & $38 \%$ \\
\hline & \multicolumn{7}{|c|}{ Rata-Rata } \\
\end{tabular}

Berdasarkan hasil Tabel 12 dapat disimpulkan rata-rata persentase jam hujan dengan waktu slippery yaitu 34\%. Dengan begitu perhitungan untuk peramalan waktu slippery yaitu menggunakan hasil peramalan jam hujan di kali dengan hasil persen slippery tersebut. Contoh perhitungan untuk menentukan waktu slippery pada bulan Januari :

Peramalan slippery bulan Januari 2019: 71,25 jam x 34\% = 23,97 jam

Adapun hasil dari penentuan slippery yang didapatkan setiap bulan pada tahun 2019, dapat dilihat pada Tabel 13

Tabel 13. Hasil Penentuan Slippery Tahun 2019

\begin{tabular}{|c|c|c|c|c|c|c|}
\hline \multicolumn{7}{|c|}{ Slippery (jam) } \\
\hline Forecast & $\begin{array}{c}\text { Historis } \\
2016\end{array}$ & $\begin{array}{c}\text { Historis } \\
2017\end{array}$ & $\begin{array}{c}\text { Historis } \\
2018\end{array}$ & $\begin{array}{c}\text { Rata-rata 3 } \\
\text { tahun }\end{array}$ & $\Delta \mathbf{t}$ \\
\hline Januari & 23,97 & 26,19 & 18,83 & 22,81 & 22,61 & 1,36 \\
\hline Februari & 18,18 & 15,88 & 18,18 & 20,01 & 18,02 & 0,16 \\
\hline Maret & 14,30 & 7,54 & 18,60 & 16,41 & 14,18 & 0,12 \\
\hline April & 18,41 & 8,00 & 20,75 & 26,40 & 18,38 & 0,03 \\
\hline Mei & 13,52 & 16,00 & 8,73 & 13,62 & 12,78 & 0,73 \\
\hline Juni & 15,65 & 18,21 & 16,37 & 12,08 & 15,55 & 0,09 \\
\hline Juli & 14,07 & 14,21 & 14,32 & 11,72 & 13,42 & 0,65 \\
\hline Agustus & 10,16 & 11,57 & 12,77 & 6,10 & 10,15 & 0,01 \\
\hline September & 7,84 & 9,50 & 8,29 & 6,71 & 8,17 & $-0,32$ \\
\hline Oktober & 19,87 & 33,55 & 12,18 & 18,83 & 21,52 & $-1,65$ \\
\hline November & 24,23 & 22,02 & 40,47 & 15,87 & 26,12 & $-1,89$ \\
\hline
\end{tabular}




\begin{tabular}{|c|c|c|c|c|c|c|}
\hline Desember & 25,40 & 29,14 & 24,28 & 32,04 & 28,49 & $-3,09$ \\
\hline
\end{tabular}

\section{Produktivitas Alat Angkut}

1. Efisiensi kerja

Setelah didapatkan peramalan jam hujan dan waktu slippery perbulannya, selanjutnya dapat dilakukan perhitungan efisiensi kerja. Pengamatan dilakukan terhadap waktu kerja produktif (Tabel 14) dan waktu hambatan (Tabel 15). Berikut waktu kerja produktif dan waktu hambatan selama 30 hari pengamatan. Dengan waktu yang tersedia di lapangan yaitu 2 shift, dengan data sebagai berikut :

Tabel 14. Waktu Kerja Produktif Bulan Januari 2019

\begin{tabular}{|c|c|c|c|}
\hline & Waktu (Jam) & hari & Total \\
\hline Sabtu - Kamis & 22 & 27 & 594 \\
\hline Jumat & 21,5 & 4 & 86 \\
\hline \multicolumn{2}{|c|}{ Total Akhir (Jam) } & 680 \\
\hline
\end{tabular}

Tabel 15. Waktu Hambatan Bulan Januari 2019

\begin{tabular}{|c|c|c|}
\hline \multirow{4}{*}{$\begin{array}{c}\text { Parameter } \\
\text { Waktu Hambatan } \\
\text { Tetap }\end{array}$} & Istirahat Lebih Awal & Exavator \\
& (jam) & 2,35 \\
\cline { 2 - 3 } & Perlambat kerja setelah istirahat & 5,75 \\
\cline { 2 - 3 } & Pulang Lebih Awal & 6,32 \\
\cline { 2 - 3 } & Pemanasan Mesin & 4,78 \\
\cline { 2 - 3 } & Alat Rusak (Break Down) & 9,27 \\
\hline Jam Hujan Efektif (JHE) & Hujan + Slippery & 95,75 \\
\hline \multirow{2}{*}{ Total (jam) } & $\mathbf{1 9 9 , 6 9}$ \\
\hline
\end{tabular}

Berdasarkan data di atas dapat diketahui bahwa pada bulan Januari dalam waktu 31 hari dari 2 shift didapatkan data sebagai berikut :

- $\mathrm{Wp}=680 \mathrm{jam}$

- Wh = Waktu Hambatan Tetap + Jam Hujan Efektif

- $\mathrm{Wh}=104,47+95,22=199,69$ jam

. Dengan data tersebut maka dapat dihitung nilai efsiensi kerja dengan perhitungan sebagai berikut :

- $\mathrm{We}=\mathrm{Wp}-\mathrm{Wh}$ 


$$
\begin{aligned}
\mathrm{We} & =680 \mathrm{jam}-199,69 \mathrm{jam} \\
\mathrm{We} & =480,31 \mathrm{jam} \\
\mathrm{E} & =\frac{\mathrm{We}}{\mathrm{Wp}} \times 100 \% \\
\mathrm{E} & =\frac{480,31}{680} \times 100 \% \\
\mathrm{E} & =71 \%
\end{aligned}
$$

Berdasarkan perhitungan di atas didapat efisiensi kerja alat pada bulan Januari yaitu $71 \%$, Fill Factor, dan Swell Factor. Dengan demikian dapat ditentukan produktivitas alat muat dengan unit excavator komatsu type PC 1250 SP. Dilakukan perhitungan setiap bulan pada tahun 2019. Berikut contoh perhitungan pada bulan Januari 2019 pada Tabel 16.

Tabel 16. Data Awal Produktivitas Bulan Januari 2019

\begin{tabular}{|c|c|}
\hline & Exavator \\
\hline Kapasitas Bucket (Hm) & 6,7 LCM \\
\hline Fill Factor (FF) & 1,09 \\
\hline Efisiensi Kerja (EK) & $71 \%$ \\
\hline Sweel Factor (SF) & 0,75 \\
\hline Cycle Time (CT) menit & 0,37 menit \\
\hline
\end{tabular}

$$
\begin{aligned}
\mathrm{Pm} 1 & =\frac{60 \times \mathrm{Ek}}{\mathrm{Cm}} \times \mathrm{Hm} \times \mathrm{FFm} \times \mathrm{SF} \\
\mathrm{Pm} 1 & =\frac{60 \mathrm{menit} / \mathrm{jam} \times 0,71}{0,37 \mathrm{menit}} \times 6,7 \times 1,09 \times 0,75 \\
\mathrm{Pm} 1 & =627,37 \mathrm{BCM} / \mathrm{jam} / \text { alat } \\
& \text { Untuk menghitung target produksi yaitu dengan cara }: \\
& =\text { Produktivitas } \times \text { jumlah alat } \\
& =627,37 \mathrm{BCM} / \mathrm{jam} / \text { alat } \mathrm{x} 4 \text { alat } \\
& =2509,5 \mathrm{BCM} / \mathrm{jam} \\
& \text { Untuk menghitung target produksi perbulan yaitu : } \\
\mathrm{P}(\text { bulan }) & =\text { Produksi } \mathrm{x} \text { waktu efektif } \\
& =2509,5 \mathrm{BCM} / \mathrm{jam} \times 480,31 \text { jam/bulan } \\
& =1.205 .331,64 \mathrm{BCM} / \text { bulan }
\end{aligned}
$$

Dengan cara yang sama, maka bulan Februari 2019 hingga bulan Desember 2019.

\section{Kesimpulan}

Dari hasil kegiatan penelitian di PT X dapat disimpulkan bahwa :

1. Hubungan antara jam hujan terhadap curah hujan, slippery, dan intensitas hujan ketiganya berpengaruh, hanya saja nilai yang pengaruhnya sangat kuat berdasarkan uji korelasi yaitu intensitas hujan dengan dengan nilai koefisien korelasi sebesar 0,704 dengan nilai signifikansi 0,000 . Nilai 0.704 berada pada interval $0,61-0,80$ termasuk kategori korelasi kuat dan nilai signifikan $0.000>0.05$ data tersebut berpengaruh terhadap jam hujan.

2. Pada penelitian ini dilakukan perhitungan prediksi jam hujan dan slippery pada tahun 2019 yang dilakukan menggunakan rumus statistika dengan fungsi sumproduct, dimana hasilnya pada bulan Januari jam hujannya 71,25 jam, dan slippery 23,97 jam. Bulan Februari jam hujan 54,05 jam dan slippery 18,18 jam. Bulan Maret jam hujan 42,06 jam dan slippery 14,30 jam dan hingga yang terakhir bulan Desember jam hujan 75,48 
jam dan slippery 25,40 jam.

3. Pada penelitian ini dilakukan perhitungan target produksi bulanan berdasarkan peramalan jam hujan, hasil peramalan target produksi tahun 2019 pada bulan Januari yaitu 1.205.331,64 BCM, bulan Februari 1.106.561,46 BCM, pada bulan Maret 1.406.595,41 BCM, dan hingga yang terakhir pada bulan Desember target produksinya yaitu 1.177.124,75 BCM.

\section{Daftar Pustaka}

[1] Abdulah. 2017. "Produktivitas Alat Gali, Muat, Angkut Dalam Pengupasan Overburden Di Pt Baturona Adimulya, Dusun Iii, Desa Supat Barat, Kecamatan Babat Supat, Kabupaten Musi Banyuasin, Provinsi Sumatera Selatan". Tugas Akhir. Program Studi Teknik Petambangan, Fakultas Teknik, Universitas Islam Bandung, Bandung.

[2] Akhtar, Hanif. 2017 "Pengaruh Adanya Outliers terhadap Analisis Statistik". www.semestapsikometrika.com. (diunduh 15 September 2019)

[3] Ari Pani Desvina, Deviwilis Anggraini. 2017. "Peramalan Curah Hujan di Kecamatan Bangkinang Barat Kabupaten Kampar Menggunakan Metode Box-Jenkins". Jurnal Sains Matematika dan Statistika, Vol. 3, No. 1, Januari 2017.

[4] Hidayat, Anwar. 2016. "Tutorial Cara Mengatasi Outlier dengan SPSS". www.statistikian.com.

[5] Mori., et al. 1997. "Effect of Chitin and Its Derivatives On The Proliferation and Cytokine Production Of Fibroblasts In Vitro". Biomaterials Journal. 18 (13) : 947.

[6] Nugroho, Sigit. 2007. "Dasar - Dasar Metode Statistika”. Bengkulu

[7] Rochmanhadi, 1982, "Alat - Alat Berat dan Penggunaannya", Cetakan III, Badan Penerbit Pekerjaan Umum, Jakarta.

[8] Prodjosumarto,Partanto. 1989, “Tambang Terbuka”, Jurusan Teknik Pertambangan, ITB.

[9] Prodjosumarto, Partanto. 1993 ."Pemindahan Tanah Mekanis". Jurusan Teknik Pertambangan Institut Teknologi Bandung. Bandung.

[10] Rambe, M. F. 2002. Analisis Kebutuhan Pasar Dan Prediksi Penjualan. Vol 2, 03-15.

[11] Saleh, Muhammad. 2011. "Prakiraan Curah Hujan Bulanan Kecamatan Tempe Kabupaten Wajo Tahun 2011 Dan 2012 Dengan Model ARIMA". Tugas Akhir. Fakultas Sains Dan Teknologi Universitas Islam Negeri Alauddin Makassar.

[12] Santoso, Singgih. 2009. "Business Forecasting”. Penerbit-Elex Media Komputindo.

[13] Sheskin, D. J. 2004. "Handbook of Parametric and Nonparametric Statistical Procedure", third Edition. Florida: Chapman \& Hall/ CRC Press.

[14] Sembiring, R.K. 1995 “Analisis Regresi”. Penerbit ITB Bandung, Bandung.

[15] Soemartini. 2007. "Pencilan (Outlier)". Bandung: UNPAD.

[16] Tri, Agus .B., Prawoto, Nano . 2017. “Analisis Regresi”, Depok.

[17] Wulandari, Dewi. 2011. "Peramalan Rata-Rata Temperatur Udara Harian Kota Pekanbaru Menggunakan Model ARIMA (0,1,1)" Tugas Akhir. Program Studi matematika, Fakultas Sains Dan Teknologi Universitas Islam Negeri Sultan Syarif Kasim Riau Pekanbaru..

[18] Yanto, Indonesianto, 2011, "PemindahanTanah Mekanis", Jurusan Teknik Pertambangan,UPN "Veteran" Yogyakarta. 